\title{
GONADOSOMATIC INDEX AND WEIGHT/LENGTH RATIO IN FOUR PENAEOIDEAN SHRIMPS IMPACTED BY FISHERY ON THE SOUTHEASTERN BRAZILIAN COAST
}

\author{
Silva, A.R. ${ }^{1}$; Santos, R.A.P. ${ }^{1}$; Moraes, I.R.R. ${ }^{1}$; Lopes, A.E.B. ${ }^{1}$; Antunes, M. $^{1}$ \& Castilho, A.L. $^{1}$ \\ ${ }^{1}$ Universidade Estadual Paulista (UNESP), Campus Botucatu, \\ Núcleo de Estudos em Biologia, Ecologia e Cultivo de Crustáceos (NEBECC). \\ *Autor correspondente: alexandre.silva@ibb.unesp.br
}

\begin{abstract}
The aim of the study was to evaluate the gonadossomatic index (IGS) and the weight/length ratio in populations of shrimps from Penaeidae (Xiphopenaeus kroyeri, Litopenaeus schmitti, Rimapenaeus constrictus) and Solenoceridae (Pleoticus muelleri) families in Ubatuba region, northern littoral of São Paulo state. The samples were conducted quarterly between 2015 and 2016 with an artisanal shrimp fishery boat equipped with double-rig nets. Were sampled 213 females that were identified, classified according to gonadal development stage and measured (CC). The gonadal stages were macroscopically classified into: immature, rudimentary and developed. Later, the females were dissected and had the gonads removed. Both body (PesC) and gonad (PesG) dry weights were obtained with an analytic balance $(0.0001 \mathrm{~g})$ and the gonadosomatic index was calculated through the equation: IGS $=(\text { PesG/PesT })^{*} 100$. Additionally, were assessed the weight/length ratio and weight gain rate. The gain weight had negative allometry indicating that the animals grows faster than the weight gain. The condition factor showed a pattern for the species with continuous reproduction in Ubatuba region, as pre-determined for tropical and sub-tropical species. The difference observed was for the only sub-Antarctic species studied (P. muelleri), which had positive allometry for weight gain $(b>3)$, indicating a weight gain higher than growth. From the IGS values was possible to separate the three pre-determined gonadal stages, proving that the macroscopically evaluation is a reliable methodology to evaluate the reproductive period in these shrimps. The results presented here serves as subside for fishery stocks management and monitoring, highlighting the importance to evaluate the distinct reproduction pattern between tropical, sub-tropical and sub-Antarctic species, mainly for management actions in species with commercial importance as well its by-catch fauna.
\end{abstract}

Keywords: reproduction, Ubatuba, condition factor. 